\title{
Study on Safety and Stability Evaluation of Waste Disposal Field of a Hydropower Station Based on in Situ Monitoring
}

\author{
Kun Sun, Houcai Sun, Yang Lu, Qianzhu Zhang \\ Changjiang River Scientific Research Institute of Changjiang Water Resources Commission, Wuhan, China \\ Email: sunkun1994@gmail.com
}

How to cite this paper: Sun, K., Sun, H. C., Lu, Y., \& Zhang, Q. Z. (2020). Study on Safety and Stability Evaluation of Waste Disposal Field of a Hydropower Station Based on in Situ Monitoring. Journal of Geoscience and Environment Protection, 8, 221-230. https://doi.org/10.4236/gep.2020.85014

Received: December 31, 2019

Accepted: May 24, 2020

Published: May 27, 2020

\begin{abstract}
Reasonable site selection, blocking to meet design standards, interception and drainage and other protective measures are the basic conditions for not causing disaster in slag disposal site. A hydropower station is located in mountainous area, the amount of slag abandoned is large, the grade of slag disposal field is high, and the site selection is difficult. On the basis of in Situ deformation monitoring, the slope stability of slag disposal site is calculated by Swedish arc method through the analysis of the scale, grade, site selection, surrounding environment, cut and discharge, blocking and protection design standards of slag disposal site. Under normal and abnormal operating conditions, the slope stability of slag disposal site meets the requirements of the code, and the results of in Situ deformation monitoring verify the calculation results of slope stability of slag disposal site by Swedish circular arc method.
\end{abstract}

\section{Keywords}

Soil and Water Conservation, Hydropower Station, Waste Disposal Field, In Situ Monitoring, Safety and Stability

\section{Introduction}

The waste disposal field is one of the important unit projects for the special acceptance of the soil and water conservation facilities of the construction project. Correctly assessing the safety and stability of the waste disposal field is an important technical guarantee for the special acceptance of the soil and water conservation facilities of the construction project. Since the special acceptance of soil and water conservation facilities in 2005 , the site selection of waste disposal fields, the design, implementation and operation of soil and water conservation 
measures have been taken as important content for the special acceptance of soil and water conservation facilities for construction projects (Sun \& Zhao, 2007) (Sun \& Yuan, 2010). For example, after the 12/20 landslide accident at the Hongtuo Residual Slag Receiving Site in Guangming New District, Shenzhen, and the 1/14 Barrier Lake Breaking Incident at Longfeng Dam in Enshi City, the outstanding safety issue of the waste disposal field of the construction project was exposed. In order to learn the lessons, the Department of Soil and Water Conservation of the Ministry of Water Resources' 2016 No. 20 document "Notice on Printing and Distributing the 'Key Points for Technical Evaluation of the Acceptance of Soil and Water Conservation Facilities of the Ministry of Water Resources"' clearly states that for the waste disposal field with a slag pile exceeding 500,000 cubic meters or a maximum slag pile height exceeding 20 meters, construction should also be consulted Stability evaluation report provided by the unit. Therefore, it is important technical guarantee for the special acceptance of soil and water conservation facilities to correctly judge the waste disposal field level, interception and drainage, blocking and protection design standards, and to correctly understand the results of safety and stability monitoring and slope stability calculation of the waste disposal field. It is of great social significance to carry out research on slag field safety and stability assessment.

In the past, the acceptance of waste disposal fields was mainly to complete relevant procedures stipulated by laws and regulations. Only before acceptance, supplement a safety and stability assessment report of the waste disposal field. The geological survey, geological type, geotechnical parameters of the waste disposal field, and the file about conditions of the base trench of the retaining wall are incomplete, often using only formulas or models for calculations. In fact, the topography and geological conditions of the spoil site, as well as the gradation, density, bulk density, c, and $\varnothing$ values of the slag body are all important parameters for assessing its safety and stability. In addition, to obtain the stability of the waste disposal fields is not only to obtain the parameter value at a certain moment, its parameter sometimes changes from quantitative to qualitative, so its internal change monitoring is also very important. Based on the calculation of safety and stability, this paper uses its internal deformation monitoring results to verify the calculation results, making the method more reliable, the results more reliable, the waste disposal field safer, and the practical value self-evident.

\section{Waste Disposal Field and Surrounding Environment}

A hydropower station is located in Wulong County, Chongqing (Sun, 2017), and is located in the lower reaches of the Wujiang River. The main task of project development is power generation, and it also has shipping functions. The project is second-class, with a large second size, a designed installed capacity of 600 MW, and an average annual power generation of 2.71 billion $\mathrm{kW} \cdot \mathrm{h}$. The total earth excavation of the project is 18.85 million $\cdot \mathrm{m}^{3}$, the total amount of filling is $7.12 \mathrm{million} \cdot \mathrm{m}^{3}$, and the amount of waste slag is $11.73 \mathrm{million} \cdot \mathrm{m}^{3}$. The waste slag is transported to five waste disposal field for centralized storage and protection. 
This article uses the GANXG waste disposal field as an example. The safety and stability assessment of the waste disposal field during the acceptance of soil and water conservation facilities is studied in order to provide a reference for the acceptance of the safety and stability assessment of the waste disposal field in similar projects. The waste disposal field is located in the gully $1 \mathrm{~km}$ upstream of the right bank dam. It is a relatively independent river ditch. The original landform of the waste disposal field is a ditch valley topography with a valley elevation of 260 to $400 \mathrm{~m}$ and an average slope drop of $15 \%$ to $25 \%$, Gutter. The elevation of the peaks on both sides of the ditch valley is $500-600 \mathrm{~m}$, and the relative height difference between the valley and the bottom of the valley is generally about 200 $\mathrm{m}$. The top of the waste disposal field has an elevation of 370 meters, the slope of side slope is 1:2, and a three-level platform is set up. The slope foot of the waste disposal field is connected to the riverside highway and the concrete mixing system. The main waste slags are the diversion channel project and the early stage of road excavation waste. The original designed waste slag volume of the waste disposal field is $3,085,000 \mathrm{~m}^{3}$, and the actual slag pile capacity is $5,683,200 \mathrm{~m}^{3}$.

According to local hydrometeorological data (Sun, 2017), the average rainfall in the project area for many years is $1001.9 \mathrm{~mm}$, and the rainy season is from April to October, and the precipitation accounts for $58.1 \%$ of the whole year. The channel of the waste disposal field is a river ditch that is greatly affected by the peak of seasonal mountain floods. There is usually water in the ditch, and the water comes in during the flood season, but the flow is small during the dry season. The abandoned slag field mainly exposes the Silurian (S) strata. The lithology is gray shale interbedded with sandstone. The formation of the strata is $320^{\circ}$ $-340^{\circ} \angle 30^{\circ}-40^{\circ}$. Most of the bedrocks on both sides of the gully are exposed.

\section{Flood Interception, Blocking and Protection Design}

\subsection{Waste Disposal Field Design Standard}

The waste disposal field is an important site for hydropower stations (Gao et al., 2011), and the flood control standard is $4 \%$ to ensure that it is not submerged during floods and heavy rains. The catchment area of the waste disposal field is $3.1 \mathrm{~km}^{2}$, and the frequency design flood peak is $56.2 \mathrm{~m}^{3} / \mathrm{s}$.

\subsection{Flood Interception Design}

According to the topographical conditions, the drainage pipe culvert is arranged on the right side of the gully in the waste disposal field, and an open drainage ditch is arranged on the left side of the upstream leaning hill to divert the water from the upstream mountain and small gully in the waste disposal field in the later period. See Table 1 for the engineering characteristics of the drainage building of the waste disposal field.

\subsection{Blocking and Protection Design}

The waste slag in the waste disposal field comes from the excavation and waste 
Table 1. Characteristics of drainage structures of the waste disposal field.

\begin{tabular}{|c|c|c|c|c|c|}
\hline Name & Upstream culvert & \multicolumn{3}{|c|}{ Downstream culvert } & Intercepting gutter \\
\hline $\begin{array}{l}\text { Drainage } \\
\text { building } \\
\text { type }\end{array}$ & $\begin{array}{l}\text { Single-hole } \\
\text { cover } \\
\text { culvert }\end{array}$ & $\begin{array}{l}\text { Single-hole } \\
\text { cover } \\
\text { culvert }\end{array}$ & $\begin{array}{l}\text { Single-hole } \\
\text { rectangular } \\
\text { culvert }\end{array}$ & $\begin{array}{l}\text { Single-hole } \\
\text { box culvert }\end{array}$ & $\begin{array}{l}\text { Ladder } \\
\text { Open } \\
\text { Channel }\end{array}$ \\
\hline $\begin{array}{l}\text { Section } \\
\text { size }\end{array}$ & $\begin{array}{l}2 \text { meters wide } \\
3 \text { meters high }\end{array}$ & $\begin{array}{l}3 \text { meters wide } \\
3 \text { meters high }\end{array}$ & $\begin{array}{c}3 \text { meters wide } \\
2.5 \text { meters high }\end{array}$ & $\begin{array}{l}3 \text { meters wide } \\
3 \text { meters high }\end{array}$ & $\begin{array}{c}\text { Base width } \\
0.8 \text { meters, } \\
1.5 \text { meters deep }\end{array}$ \\
\hline $\begin{array}{l}\text { Length } \\
(\mathrm{m})\end{array}$ & 624 & 360 & 240 & 54.23 & $\begin{array}{c}\text { On-site } \\
\text { determination }\end{array}$ \\
\hline
\end{tabular}

in the first phase of the right bank. Most of them are shale with poor mechanical properties. Permanent protective body is used for joint blocking and protection to ensure the safety and stability of the waste disposal field. The foundation of the foot guard retaining wall at the bottom of the spoil ground is dug to weak weathering, the block-filled foundation is dug to $2 \mathrm{~m}$ under full weathering, the burial depth is not less than $3 \mathrm{~m}$, and it is rolled in layers. The foot guard retaining wall is cast with C20 stone ballast, and the comprehensive slope at the bottom of the ditch is steep. Before construction, unfavorable factors such as humus soil, weeds and tree roots on the original slope of the waste disposal field will be removed. Within the range of $280 \mathrm{~m}$ elevation platform, limestone (or sandstone-containing) stone slag is used as a filler, which is filled in layers and rolled to form a rockfill slag retaining dam with a layer thickness of about $80 \mathrm{~cm}$. The rolling equipment adopts $18 \mathrm{t}-25 \mathrm{t}$ ton-level vibration roller, and the rolling number of each layer is not less than 4 times. The outer side of the rockfill slag retaining dam filling area is constructed according to the reinforced soil slope. Below the $280 \mathrm{~m}$ platform, dry masonry is used for permanent slope protection, and above the $280 \mathrm{~m}$ platform, turf is used for permanent slope protection.

\section{Safety Monitoring Results and Analysis}

In February 2013, safety monitoring instruments were set up on the right bank waste disposal field, and one set of inclinometers were respectively arranged at the elevations of EL335 m, EL320 m, EL300 m, and EL280 m, and the drilling depths were $45 \mathrm{~m}, 40 \mathrm{~m}, 40 \mathrm{~m}$, and $35 \mathrm{~m}$, respectively. It has penetrated into the bedrock surface $5 \mathrm{~m}$ in order to monitor the lateral displacement of the deep layer of the slag field. In March of the same year, the inclined hole in the abandoned slag field obtained the reference value. The axis depth of the important monitoring hole (orifice elevation: EL335.0 m) - cumulative displacement curve is shown in Figure 1, and the cumulative displacement process line of the oblique pipe orifice is shown in Figure 2.

\section{Stability Assessment of Current Waste Disposal Field}

According to the actual 1:1000 actual topographic map data of the waste disposal field of the hydropower station provided by the construction unit, check the 

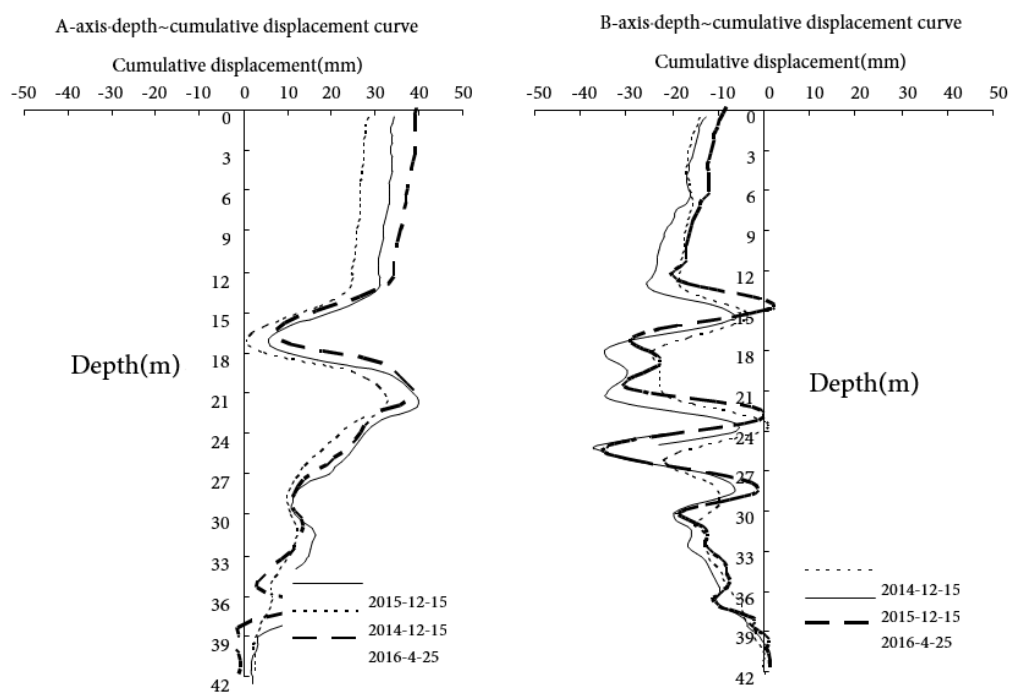

Figure 1. Cumulative displacement curves of the inclinometer dise measured elevation by EL335.0 in the waste disposal field.

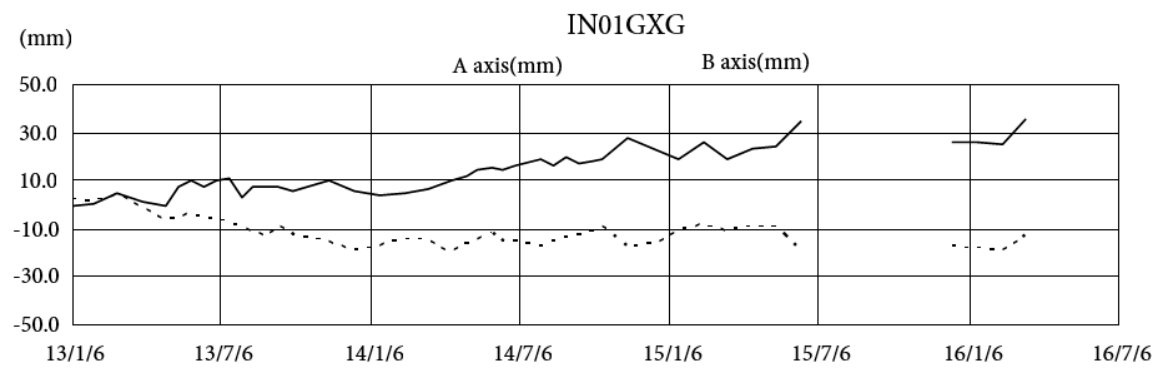

Figure 2. Cumulative displacement process lines of the inclinometer pipe at 45 in the waste disposal field. Note: 1) Positive value of a axis indicates displacement towards the river bed, negative value is opposite direction; positive value of $\mathrm{B}$ axis indicates displacement towards downstream direction, negative value is upstream direction. 2) The discontinuous period of the cumulative displacement process line (one dashed line and one solid line) of the oblique pipe orifice is instrument damage and cannot be monitored.

comparison of the actual slag heaping amount of the current waste disposal field with the original design slag heaping amount and the maximum pile height statistics of the current waste disposal field (Table 2).

\subsection{Evaluation Basis and Standards}

According to the relevant codes and regulations such as "Code for Design of Soil and Water Conservation Engineering" (GB51018-2014), "Technical Specification for Water Conservancy and Hydropower Engineering" (SL575-2012) and "Code for Design of Embankment Engineering" (GB50286-2013), The level 2 waste disposal field is shown in Table 3, and the control standard of anti-sliding stability safety factor is shown in Table 4.

\subsection{Calculation Method for Slope Stability of Waste Disposal Field}

Because the waste disposal field is a channel type, its instability mode is mainly 
Table 2. The volume and the maximum pile height of the waste disposal field.

\begin{tabular}{ccccc}
\hline $\begin{array}{c}\text { Plan and design } \\
\text { slag pile } \\
\begin{array}{c}\text { (Million } \\
\text { cubic meters) }\end{array}\end{array}$ & $\begin{array}{c}\text { Actual } \\
\text { slag pile } \\
\text { (Million } \\
\text { cubic meters) }\end{array}$ & $\begin{array}{c}\text { Change in slag } \\
\text { Amount } \\
\text { (Million } \\
\text { cubic meters) }\end{array}$ & $\begin{array}{c}\text { Increase or } \\
\text { decrease from } \\
\text { the original } \\
\text { design }\end{array}$ & $\begin{array}{c}\text { Current waste } \\
\text { disposal field } \\
\text { maximum slag } \\
\text { pile height (m) }\end{array}$ \\
\hline 300.85 & 568.32 & +267.47 & $+88.90 \%$ & 65.00 \\
\hline
\end{tabular}

Table 3. The Levels and standards for the waste disposal field.

\begin{tabular}{cccc}
\hline $\begin{array}{c}\text { Waste disposal } \\
\text { field level }\end{array}$ & $\begin{array}{c}\text { Slag pileV } \\
\text { (Million cubic meters) }\end{array}$ & $\begin{array}{c}\text { Slag height } \\
\mathrm{H}(\mathrm{m})\end{array}$ & $\begin{array}{c}\text { The degree of harm caused by the } \\
\text { waste disposal field accident to the } \\
\text { main project or the environment }\end{array}$ \\
\hline 1 & $2000 \geq \mathrm{V} \geq 1000$ & $200 \geq \mathrm{H} \geq 150$ & Serious \\
2 & $1000>\mathrm{V} \geq 500$ & $150>\mathrm{H} \geq 100$ & More serious \\
3 & $500>\mathrm{V} \geq 100$ & $100>\mathrm{H} \geq 60$ & Nothing serious \\
4 & $100>\mathrm{V} \geq 50$ & $60>\mathrm{H} \geq 20$ & Lighter \\
5 & $\mathrm{~V}<50$ & $\mathrm{H}<20$ & Non-hazardous \\
\hline
\end{tabular}

Table 4. Safety factors of anti-sliding stability for the waste disposal field.

\begin{tabular}{ccccc}
\hline \multirow{2}{*}{ Application } & \multicolumn{4}{c}{ Waste disposal field level } \\
\cline { 2 - 5 } & 1 & 2 & 3 & 4 \\
\hline Normal use & 1.25 & 1.20 & 1.20 & 1.15 \\
Abnormal use & 1.10 & 1.10 & 1.05 & 1.05 \\
\hline
\end{tabular}

reflected in the sliding stability of the waste disposal field along the trench. The focus is on calculating the anti-sliding stability of the waste disposal field slope (Ma et al., 2011). According to the relevant code (Gao et al., 2011), rationalization software is used for the stability analysis and calculation of the waste disposal field, and the slope stability of the waste disposal field is calculated by the Swedish arc method. The seepage effect calculation method is the effective stress method. The slope stability (Figure 3 ) can be calculated according to Formula (1).

$$
K=\frac{\sum c l+[(W-U) \cos \theta+D \sin (\alpha-\theta)] \operatorname{tg} \varphi}{\sum W \sin \theta+D \cos (\alpha-\theta)}
$$

In the above functions, $K$ is the safety factor for the calculation of the remaining sliding force of the entire sliding body; $l$ is the length of the sliding surface of a single soil strip $(\mathrm{m}), l=b \sec \theta$; $W$-the gravity of the strip $(\mathrm{kN})$; Saturation severity; $U$ is Buoyancy $(\mathrm{kN})$ to which the bar is subjected; $D$ is Permeability $(\mathrm{kN})$ to which the bar is subjected, which is obtained by integrating the pore water pressure gradient field; $\theta$ is Gravity line of the bar and passing through the bar The angle (degrees) between the midpoint radius of the bottom surface; the angle (degrees); $\alpha$ is angle between the penetration force of the block and the horizontal line; $c, \varphi$ is the shear strength index of the soil. When the total stress 


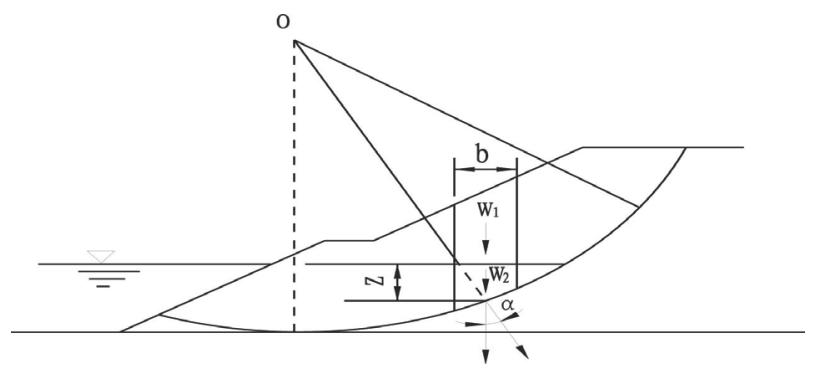

Figure 3. Calculation diagram of the Swedish arc method.

method is used, the total stress index is taken, when the effective stress method is used, the effective stress index is taken.

\subsection{Calculation of Slope Stability in Waste Disposal Field}

According to the current status of the waste disposal field, a typical Section 1-1' is taken for the waste disposal field. As shown in Figs. The upper and lower sides and bottom of the foundation rock and soil in the slope calculation model are used as impervious boundaries. The horizontal range is from the foot of the slope to the top grading line, and the vertical range is above the original ground line. The slag bodies in the waste disposal field are mainly shale blocks and some are sandstone and limestone blocks. Table 5 shows the main parameters of the filling materials (Figure 4 and Figure 5).

According to the same specifications as above, the anti-sliding stability calculation of the waste disposal field should be divided into normal operating conditions and extraordinary operating conditions. Normal operating conditions mean that the waste disposal field is operating under normal and long-lasting conditions. When the waste disposal field is in the final abandoned slag state, there is no seepage or stable seepage of the slag body; abnormal operating conditions mean that the waste disposal field is under normal operating conditions Encountered an earthquake above or above VII.

Under various operating conditions, the stability coefficient of the Section 1-1' of the slag field is shown in Table 6, and the most unfavorable sliding surface is shown in Figure 6 and Figure 7.

\section{Conclusion and Suggestion}

\subsection{Conclusion}

The waste disposal field is a relatively independent river ditch. The elevation of the valley bottom is $260-400 \mathrm{~m}$, the elevation of the peaks on both sides of the valley is $500-600 \mathrm{~m}$, and the relative height difference from the valley bottom is generally about $200 \mathrm{~m}$. The top elevation of the slag field is $370 \mathrm{~m}$. At the foot of the riverside road and the concrete mixing system, of which the "waste disposal field slope at the foot of the riverside road and concrete mixing system" and the four main principles of the site selection of the waste disposal field of the hydropower project are that "the abandoned slag does not occupy the river channel 


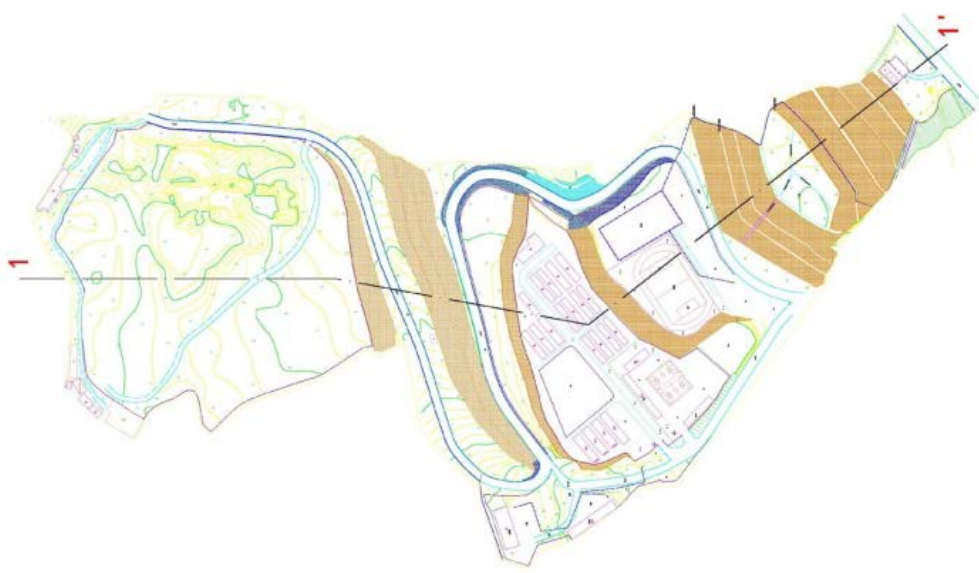

Figure 4. The plan view of the waste disposal field for slope stability evaluation.

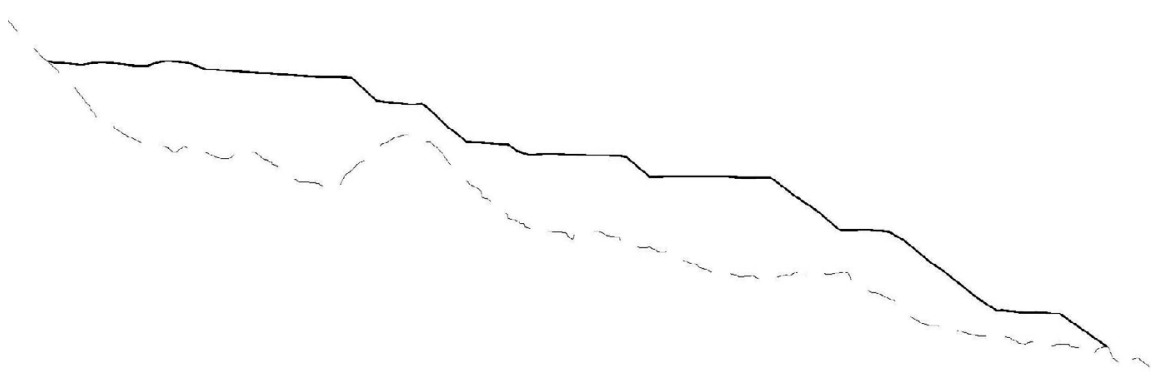

Figure 5. Typical profile for slope stability calculation of the waste disposal field.

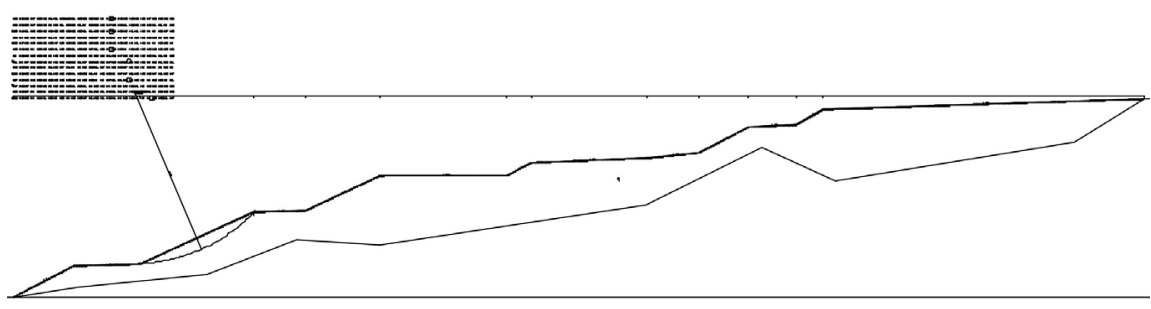

Figure 6. The failure surface of Section 1/1' under normal condition of the waste disposal field.

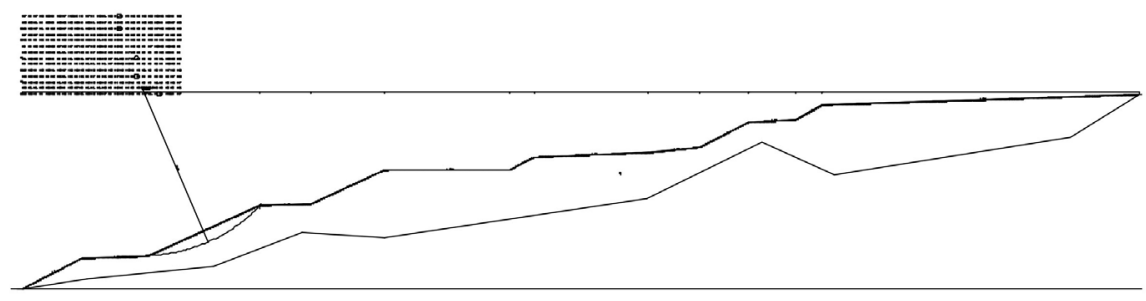

Figure 7. The failure surface of Section 1/1' under abnormal condition of the waste disposal field.

Table 5. Parameters for main backfill material of the waste disposal field.

\begin{tabular}{ccc}
\hline Cohesion C (kpa) & Internal friction angle $\varphi\left(^{\circ}\right)$ & Lithology of slag filler \\
\hline $0-5$ & $24-28$ & $\begin{array}{c}\text { The slag lithology is dominated by shale stones, } \\
\text { some are sandstone and limestone stones }\end{array}$ \\
\hline
\end{tabular}


Table 6. Slope safety factors for Section $1 / 1$ ' of the waste disposal field.

\begin{tabular}{cccc}
\hline Section & $\begin{array}{c}\text { Normal } \\
\text { operating conditions }\end{array}$ & $\begin{array}{c}\text { Abnormal } \\
\text { operating conditions }\end{array}$ & Code specifies safety factor \\
\hline $1-1^{\prime}$ & 1.22 & 1.11 & $\begin{array}{c}\text { normal operation: } 1.20 \\
\text { Abnormal operation: } 1.10\end{array}$ \\
\hline
\end{tabular}

and does not affect "Flooding floods without leaving hidden dangers" is somewhat contrary, because the project area has steep hills and high slopes, and the site selection of the waste disposal field is difficult to meet the four principles of site selection. Therefore, the waste disposal field is an important site for hydropower stations. High standard design guarantees flood prevention safety.

The safety monitoring results show that the maximum deformation of the recent monitoring data in the direction of the riverbed of the waste disposal field is $11.12 \mathrm{~mm}$, which is mainly due to the influence of road construction above and excavation of the foundation below. This hole is relatively deformed, and the cumulative displacement of the orifice is $36.23 \mathrm{~mm}$. No abnormal changes were seen in the holes. At the same time, according to the results of Table 6, Figure 6 and Figure 7, the current status of the waste disposal field slope stability meets the requirements of the code, and the waste disposal field slope is stable.

Based on the comprehensive analysis and evaluation of the above-mentioned waste disposal field, and nearly ten years from the design and implementation of the waste disposal field, the in-situ deformation monitoring results and review calculations and other indicators show that the waste disposal field has basically reached a relatively stable state.

\subsection{Suggestion}

The current waste disposal field is of a relatively high level. In the later period, the interference of the upper production and living activities on the waste disposal field should be gradually reduced. The flood interception and drainage (water) facilities of the waste disposal field are inspected, dredged and repaired regularly (especially before the flood). In order to prevent drainage from penetrating into the waste disposal field, continue to monitor the deformation of the waste disposal field, it is strictly forbidden to arrange buildings or construction sites at the downstream of the waste disposal field channel or at the ditch mouth.

\section{Acknowledgements}

This paper is supported by the Fundamental Scientific Research Business Expenses for Central Public Welfare Research Institutes (Program SN: CKSF2019413/CQ).

\section{Conflicts of Interest}

The authors declare no conflicts of interest regarding the publication of this paper. 


\section{References}

Gao, B. L., Zhou, Q., \& Gao, W. L. (2011). Discussion on Design of Soil and Water Conservation Measures in Waste Disposal Field of Hydropower Project. Soil and Water Conservation in China, 36-38.

Ma, X. Y., Di, L., Fu, Z. E., Hou, T., Zhang, F., \& Hu, X. H. (2011). Slope Stability Analysis and Soil and Water Conservation Measures of No. 2 Waste Disposal Field of Zhuchaxia Hydropower Station. Soil and Water Conservation in China, 57-59.

Sun, H. C. (2017). Report: Opinions on Technical Assessment of Soil and Water Conservation Facilities of a Hydropower Station. OH: Changjiang River Scientific Research Institute of Changjiang Water Resources Commission.

Sun, H. C., \& Yuan, P. J. (2010). Status and Development Direction of Soil and Water Conservation Monitoring in Development and Construction Projects. Soil and Water Conservation in China, 36-38.

Sun, H. C., \& Zhao, Y.-J. (2007). Status and Development Trend of Soil and Water Conservation for Development and Construction Projects in China. Soil and Water Conservation in China, 50-52. 